\title{
The Role Played by Management
}

\section{Owner-Manager Versus Professional Manager Models}

Looking into the roles played by owners who manage their own companies revealed two patterns. Originally, almost all of the documented firms were owned and managed by a founder, or a group of founders. That meant that during the first generation of owners, management and ownership were largely combined. Over time, however, this pattern evolved, and an increasing number of firms disconnected ownership roles from managing the operational part of the business. Typically, this took the form of engaging an outside CEO, or external management team, not connected to ownership.

\section{Multi-generation Owner-Managed Firms}

Sefar, the oldest company of the research project, was unique in that. For many years, the company's management was in the hands of professional managers and only more recently took the step to appoint a representative of ownership for management.

If family members wished to become active in Sefar, they were required to have had the appropriate qualifications. In 2018, Christoph Tobler (1957) was the only member of a founding family holding an active top management role in Sefar AG. He had become CEO in 2005, after earning an engineering degree and an MBA, then working for McKinsey and having made a career in the chemical industry. His great-grandfather of the same name had entered the company 150 years earlier. Before Christoph Tobler, Sefar had no family member as CEO, only external managers. The chairman of the board of directors was not member of any of the owner families. ${ }^{1}$

\footnotetext{
${ }^{1}$ Adapted from Sefar company profile.
} 
Among the companies still owner-managed in later generations, Rüeger, Jura, Ricola, and Oetiker continued to be owner-managed in the third generation. Of those four companies, however, two changed management after the conclusion of the interviews for this publication.

\begin{abstract}
Rüeger remained a family-owned company with the family still holding 100 percent ownership. After the retirement of Rolf Rüeger, son of the founder, the 3rd generation took over in 1991 with Bernard Rüeger, grandson of the founder, nominated as managing director, later CEO and eventually Chairman of the Board. Bernard initially trained as an engineer at EPFL but changed into business studies as he "found engineering boring and I am a businessman." His younger brother, Jean-Marc Rüeger, joined shortly thereafter following a stint in the IT sector and initially assumed an administrative role, then he became head of manufacturing. In 2012, on the 70th anniversary of the company, Bernard Rüeger turned over the CEO role to his brother Jean-Marc and assumed the role of Chairman while still responsible for business development. ${ }^{2}$
\end{abstract}

Without a fourth generation to take over, the Rüeger family decided to sell the company to a corporate owner with whom a longer-term cooperation had already existed.

At Ricola, Felix Richterich, representing the third generation of the founding family, had stepped back in 2003 as CEO to concentrate on the role of Chairman. After the unexpected death of the company CEO a few years later, Richterich had to step in again and assume the dual role of Chairman and CEO. In 2019 (after the closure of the data analysis and interview for this project), Felix Richterich stepped down from the CEO role again and a new, external CEO was appointed. One family member was the chief marketing officer (CMO) and thus the only member of the owning family in an operational role. A representative of the fourth generation joined the company board and relinquished an operational role.

At Oetiker Group, Thomas Meier-Bickel, representing the third generation of the Oetiker founding family, had been with the company for more than 10 years, 6 years of them as CEO. He had come to the firm with a background in finance and banking, with previous studies in business administration. He admitted that, while he did understand technology, he could not do engineering drawings himself. The fourth generation, according to Meier-Bickel, was still very young!

The experience of these companies, starting as family businesses, demonstrated that the combined owner-management roles were difficult to sustain beyond more than three generations. Since many of the companies in the research were in the B2B space, and in the technical sector on top of that, successive generations often had not pursued a sufficiently technical education, or subsequent careers, to be able to play an operational role.

\footnotetext{
${ }^{2}$ Adapted from Rüeger company profile.
} 


\section{First Generation Owner-Managed Firms}

How come there is still such a large number of owner-managed firms in the first generation when apparently firms begin to have difficulty recruiting ownermanagers beyond the third generation? Of the seven firms that can be categorized as first generation owner-managed, two, namely Medartis and u-blox, are among the youngest firms in the sample and are still being managed by the founders. In the case of Medartis, company founder Thomas Straumann and co-founder Willi Miesch, in the role of CEO, had been with the firm since its inception in 1997. At u-blox, the three founders, former students at ETH Zurich, remained with the firm in operating roles, although their ownership has been diluted to a small percentage. Since these two firms are less than 25 years old, being still led by the first generation management should not come as a surprise.

Quite different, however, was the experience at six firms included in the research project that "still" run under second generation owner-management despite the fact that they are, in some cases, more than 100 years old. All of these firms experienced recent ownership changes with new owners assuming combined ownership and management roles, essentially setting the clock back to zero.

At Sécheron Group, an investor team had assumed ownership in 2005 and filled both the roles of board chairmanship and the CEO, although not by the same person. Similar was the situation at Burckhardt Compression where the executive team that led the MBO out of the parent company in 2002, and later launched an IPO in 2006, took on both management and board leadership positions.

As for the three other firms (Acutronic, Lantal, and Fraisa), owner-managed by their founders, who sold their companies to new owners who continued in ownermanager roles.

Acutronic changed hands two times, always with new owners practicing the owner-manager model. Founded in 1973 by entrepreneur Marxer, the company was acquired in 1996 by a new owner, Jung, who continued to manage the company until 2015, when it was sold again to the Aigrin family to be managed by one of their family members.

\section{Second Generation Owner-Managed Firms}

Of the owner-managed firms in the 2nd generation, special circumstances usually led to a continuation of the dual roles of ownership and operational leadership. In the case of Wyon, this was facilitated since the second generation was part of the startup operation in the first place. In the case of Sylvac, the owning Meyer and Schnyder families were able to have the second and third generations active in management and in the roles of Chairman and CEO. All of the family members, however, had technical backgrounds relevant to the Sylvac business. At Filtrox ownership changed and the company was currently owner-managed by the second generation of the Rusch family who had entered into ownership in the 1980s. 
The owners of EAO faced a particular challenge. Originally started by two entrepreneurs, the business was split after both founders had passed away. The Loosli family assumed ownership of the company, which then had to be transferred to the second generation.

The Loosli family assumed control of EAO following a split in ownership after the death of the founders. Widow Dora Loosli and her four children all became shareholders. Two sons entered the business with Kurt Loosli, Jr. eventually becoming CEO. Kurt Loosli brought extensive technical background to his role. After graduating from ETH Zurich, he joined a Swiss firm Ascom dealing with microelectronics and sensors. After earning his MBA at Manchester Business School, he joined ADL Consulting where he stayed three years, becoming head of R\&D and deputy CEO of ADL in Switzerland. He joined EAO in 1997. Kurt Loosli's older brother, also in the company, concentrated on the commercial aspect of the firm. ${ }^{3}$

\section{Challenges of Sticking with Owner-Manager Model}

One of the more difficult issues for family-owned and -managed firms to transition to the next generation was finding talent who could effectively play both the owner and the manager roles. If this could not be accomplished, the owners had no other choice but to split ownership and management or, as occurred in some instances, find talent outside the family, or even selling the company outright. Because many founders and owners found divesting their company difficult, the present research documents a number of situations where a great deal of effort and care was expended to keep ownership and management in the family.

Based on the research, it was found that, traditionally, owners were reluctant to appoint daughters to leading management roles in their firms. This was most likely due to the fact that daughters, years ago, were not encouraged to join technology or science-related curricula. Similarly, some 50 years ago it was not a matter of course, or even considered normal, to appoint a daughter to head a family business. Today, these cultural norms have obviously changed.

A first recourse, for some families, was to appoint a son-in-law. Of the five companies, where this was at one time the chosen course, two ended unsuccessfully and were later reversed, and three turned out to be very successful for the companies. This brings to mind a member of a patrician Bernese family, himself a member of the 13th generation, who, when asked how the family could keep much of its assets together, quipped: "Beware of the pièces rapportées."

For some family-owned companies, in-laws can represent talent that moves a business forward. At Kuhn Rikon, Wolfgang Auwärter who had married the daughter of Henri Kuhn, a son of the company's founder, became CEO and later also Chairman of Kuhn Rikon during a phase of strong growth. At Felco, the

\footnotetext{
${ }^{3}$ Adapted from EAO company profile.

4"Beware of the in-laws."
} 
founder's son-in-law took over management and led the company for 28 years before turning it over to the third generation.

Throughout its history, Felco remained a family-owned company. Ownership was in the hands of Félix Flisch's descendants and their families. Félix and Juliette Flisch had one daughter and one son. Flisch managed the company until 1974, when he turned management over to his son-in-law Eric Perrin, who was CEO until 2002, when his son Laurent Perrin took over for the 3rd generation, from 1 January 2003, and remained CEO until 2011, at which time Christophe Nicolet was appointed CEO, who was the first non-family member after 66 years to head the firm. ${ }^{5}$

\section{Separating Ownership and Management}

For more than half of the researched companies ( 21 out of 36 ), the initially practiced combination of ownership and management had given way to separating the two roles. The rationale for this split was usually based on the fact that from among the owners, suitable successors with the relevant backgrounds did not exist. In addition, there were often experienced professional managers present at the firms who were better qualified and versed in the technologies crucial to the businesses.

At family-owned companies, a split entailed retrenching to running and chairing the board instead. This concentration on the role of the board chair might not have occurred after the first generational ownership turnover, but by about the third generation it was the norm. Such transfers from the third generation onward occurred at Plaston and at Felco. The experience of Caran d'Ache demonstrated the occasionally difficult process of moving from the combined role to splitting responsibilities between owners and management.

With the retirement of Jacques Hübscher, Jr., in 1997 as CEO, the long reign of three generations of Huebschers as CEOs of Caran d'Ache came to an end. For the first time, a CEO managed the company without any connection to the three owner families. The transition proved difficult. To find a person who could fit into the family business culture and still assume the role of the CEO was not easy. After the first two years a change became necessary and Silvio Laurenti was appointed CEO in 1999. Achieving considerable success with a challenging strategy, Laurenti remained until his retirement in 2008. A new CEO joined, only to leave again in 2011. To fill in temporarily, Laurenti came back out of retirement until a permanent successor, Jean-François de Saussure, was ready to take on the CEO role. Although without relevant industry background, de Saussure had previously worked at a family-owned company in the region that prepared him for the intricacies of managing a firm with three families as owners. Jacques Hübscher remained a board member until 2012 when his daughter Carole Hübscher, representing the 4th generation, assumed the board chair. ${ }^{6}$

\footnotetext{
${ }^{5}$ Adapted from Felco company profile.

${ }^{6}$ Adapted from Caran d'Ache company profile.
} 
Plumettaz also experienced the difficulty of changing from family ownership into splitting the roles, as fewer members of ownership were willing to assume operating roles in the company. When this was combined with a transition in ownership to a financial owner, the risks of encountering problems for the business are enhanced.

For almost 80 years, up to 2008 , Plumettaz had remained a family-owned company with more than 40 shareholders. However, few family members were active in the business. When Gerard Plumettaz retired at age 65 in 2008, a private equity firm took over 70 percent of the share capital. A holding company was created that held all the assets and the PE firm appointed an outsider as CEO. However, the appointment did not work due to cultural differences with a CEO that came from a large company context. Two years later, in 2010, the PE company invited the family back into management. A different PE firm has since acquired the stake and a new external CEO was recruited. Governance rested with a small board of four members. Members were Denis Plumettaz, the newly hired CEO and two PE company representatives. The company's new CEO, Philippe Prate, an engineer by training and education $(\mathrm{PhD})$, had international experience, was a French national and spoke several languages. Both Denis Plumettaz and Philippe Prate were also shareholders in the company. ${ }^{7}$

To avoid the risk of bringing in unsuitable executive talent that can lead to a culture clash, some owners take the route of recruiting from within and often promoting very young managers to senior positions, leapfrogging possible family appointments. The experience at Fraisa serves as an example.

At Fraisa, as early as 1982, as Hans Stüdeli was approaching retirement at the age of 62, he was beginning to plan for the 3rd generations of Stüdelis to take over. As the father of three daughters, none of them with a technical background or interest in the business, he reached out to his sons-in-law for future leadership of the firm. Two joined management of Fraisa and, together with the production and operations manager, continued to lead the company, with Hans Stüdeli continuing in the board chair.

Taking over management responsibility was a big challenge for both sons-in-law as one of them had a background in law and economics, and the other one in law exclusively. Supported by operational management, this worked well in the 1980s. A business downturn for Fraisa, along with changes in the industry in the early 1990s, and the company entering a period of losses, caused friction among the Stuideli family. As the company was struggling to catch up in the development of hard metal tools, Hans Stüdeli, at the age of 75, pulled the breaks. He orchestrated a change in management, which resulted in one of his sons-in-law leaving the company in 1995.

Stüdeli, confronted with the risks faced by his company, realized that Fraisa needed professional leadership from outside the family. He approached Josef Maushart, who was just 30 years old and had successfully led the development team for hard metal tools. Stiudeli first offered him the role of head of research and development and to join the management leadership team, but soon he followed up with an enhanced proposal for Maushart to assume the management of the entire company by becoming its CEO. Maushart could pull two other young managers into the leadership team and, together with the senior and experienced

\footnotetext{
${ }^{7}$ Adapted from Plumettaz company profile.
} 
production and technology head, and support by the remaining family members, assumed management of Fraisa. ${ }^{8}$

The separation of ownership from management roles occurred earlier in the development cycle of larger firms and those who went public. When Komax founder Koch turned over his company to management and later moved to MBO and IPO, the company's management was assumed by executives who had been with the company for several years. At maxon, a gradual withdrawal of the Braun family, majority owners of the company, to board roles could be observed.

\begin{abstract}
Management of maxon was in the hands of professional managers with long experience at the company, in the industry and deep roots in the relevant technology. With the exception of Karl-Werner Braun, the company's main shareholder, ownership did not get involved in operative management other than remaining close to technology. In its more than 50-year history, the company knew only three CEOs who also served as board chairmen for much of their tenure. ${ }^{9}$
\end{abstract}

The same process took place at Bachem where founder and majority owner Grogg turned over operational responsibility of the company to professional management. At $\mathbf{C}+\mathbf{M}$, long a semi-public firm, management had been in the hands of non-ownership related executive teams. At LEM, a public company for decades, management had been traditionally assumed by professional management teams.

In summary, it can be observed that, as a company matures and grows beyond the founding generation, and even moves toward eventual public ownership, professional management teams became the norm along the line. Ownership then concentrates on the board and governance.

\title{
The Challenge of Recruiting Successors
}

The struggle to maintain family ownership for as long as possible sometimes resulted in stories of unusual hiring and recruiting. As the end of family control appeared in sight, owner-managers were challenged to find suitable successors whose views were in line with their own company philosophy. In the case of both Fraisa and Thermoplan, the owners reached deep inside their own company and appointed young managers who had proven their leadership and managerial skills and yet were not part of the family. In both cases, the owners eventually transferred part, or all, of their ownership stake to the younger managers.

At Fraisa, Hans Stüdeli, second-generation owner, recruited Josef Maushart, a young successful development manager within the company, to take over. Years later, he also was to facilitate the MBO of Fraisa allowing Maushart and his family to become majority owner of the company. At Thermoplan, Domenic Steiner and his

\footnotetext{
${ }^{8}$ Adapted from Fraisa company profile.

${ }^{9}$ Adapted from maxon company profile.
} 
wife Esther also reached deep inside their own company to look for a replacement and found Adrian Steiner who had been at Thermoplan for just 9 years.

In 2006, Domenic Steiner approached Adrian Steiner (not related) to work with him on a succession plan. Adrian Steiner had joined Thermoplan in 1997, just as the introduction of the first automatic coffee machine took place. Adrian Steiner had completed an apprenticeship as electrical installer and attended the Executive Master of Business Administration (EMBA) program of the University of St. Gallen (HSG). Adrian Steiner personally experienced the enormous growth of Thermoplan from 35 to almost 300 employees and was familiar with all facets of the company. In 2008, two years into this process of succession, company founder Domenic Steiner, then 71 years old, decided to step back. In 2009, when Adrian Steiner was appointed CEO, the shareholding structure of Thermoplan was also changed. Adrian Steiner was allowed to take over 20 percent of the shares, with the remainder split between Domenik and Esther Steiner. ${ }^{10}$

Sometimes, successors were not found inside a company and had to be recruited externally. The experience at Lantal and Jura showed how, through the use of headhunters, successors were identified.

Because Urs Baumann's daughters did not want to take over the company, Lantal started to look for other succession options. A headhunter was retained, and a solution was found. In 2003, Dr. Urs Rickenbacher joined the company as the new CEO. A graduate from the University of St. Gallen, he was previously head of the German subsidiary of the furniture manufacturer USM. One year after his appointment, in 2004, the majority of the ownership of Lantal was transferred to Urs Rickenbacher and other senior executives in a management buy-out. ${ }^{11}$

A similar story unfolded at Jura, where the group of senior managers who had taken over from company founder Henzirohs, had been intensively looking for a successor since the management team was approaching retirement age:

Oswald Müller, member of the Jura management team, and his senior management colleagues, all approaching retirement, were intensively looking for a new CEO to take over. After unsuccessful appointments of external managers, the search company suggested to take a closer look at Emmanuel Probst, already on their board, before he would be hired away by some other company. Probst, with a degree from the University of St. Gallen and marketing experience at Procter \& Gamble and Baxter, a medical company, joined Jura in 1991 on a fulltime basis. Later on, Emmanuel Probst was also to become Oswald Müller's son-in-law. Newly in charge, Emmanuel Probst unleashed a process of transformation that was to take about 15 years with a focus on espresso machines. ${ }^{12}$

Possibly the most unusual search for management succession was recalled by Christian Aschwanden who recounted his hiring experience at Felchlin where Max Felchlin, Jr., second generation of ownership, was searching for someone to replace

\footnotetext{
${ }^{10}$ Adapted from Thermoplan company profile.

${ }^{11}$ Adapted from Lantal company profile.

${ }^{12}$ Adapted from Jura Espresso Machines company profile.
} 
him as the CEO of the company. Prior to the search, Max Felchlin, Jr., had assigned ownership of the company to an independent foundation:

At the end of this process of re-structuring ownership, Max Felchlin, Jr., still needed to find a replacement for his role as CEO. Since his sons were not considered, the next generation of management had to come from outside the family. In line with his eccentric ways, he orchestrated a recruiting process that the eventual chosen person, Christian Aschwanden, remembers distinctly: One day in 1991, I was working then with Lindt \& Sprüngli, I saw an ad describing the opening of the CEO job at Felchlin. Given my background as a food processing engineer and working for Lindt, I got up my courage and applied. I was invited for an interview, but venue and format were rather unique. All applicants, including myself, and there were many of us, were invited on a boat ride on Lake Lucerne. On the boat were also all senior managers of Felchlin, Max, Jr., included, and we were encouraged to ask questions. After this event, I returned home and did not hear for weeks. Then, suddenly, one evening, I got a call at home (I lived near the town of Schwyz), with Max, Jr., on the line asking me to come on over to his home. That is when I was offered the job (Aschwanden, CEO). ${ }^{13}$

The experience of finding management, or at times ownership talent, showed how long-serving owners found the courage to pluck very young talent from unusual circumstances and to heave them into positions of responsibility. On all accounts, the likes of Christian Aschwanden at Felchlin, Emmanuel Probst at Jura, Josef Maushart at Fraisa or Urs Rickenbacher at Lantal turned out to be company leaders who would exert transformative leadership and bring their companies to new and higher levels, thus assuring the longevity of the firms entrusted to them.

\section{Practicing a Unique Management Style}

Reviewing the experience of managers from larger companies, outside the specific SME and family-type company environment, being appointed to a lead position at a demonstrably smaller, medium-sized company and running into difficulties in the process suggested that there was indeed a special way as to how these companies were managed. Core principles unearthed in the research and interviews included flat hierarchies, combined with open communication, allowing lower levels to also be heard by company leadership. As the Sefar experience shows, communication was also initiated from the top.

Sefar tried to keep qualified people in the firm by offering an attractive working environment, providing additional monetary benefits and through an express personal appreciation of the employees. For example, the current CEO took time to go out of his way and talk to the people in his employ. He went to the employees at the machines to congratulate them to their birthdays. ${ }^{14}$

\footnotetext{
${ }^{13}$ Adapted from Max Felchlin company profile.

${ }^{14}$ Source Sefar company profile.
} 
Robert Lombardini, Chairman of Sécheron Groupe, had extensive experience in larger corporate environments prior to assuming his leadership role at Sécheron. Some corporate management principles, such as cost control methods and restructuring, applied to smaller companies as well.

For us at Sécheron, the KMU (SME) management principles are important. We run every division as a separate KMU. KMU management means that everyone speaks to everyone, and everyone is involved in the operations of the company (Lombardini, Chairman). ${ }^{15}$

Both Lantal and FISBA were led by CEOs hired from the outside and they both echoed Lombardini's observations on SME leadership style.

Lantal had an open, personal culture that invited independent thinking and committed work. Everybody was invited to contribute ideas and had some personal space that also tolerated mistakes. Every three months Urs Rickenbacher took the time to spend a day with about ten new employees and to discuss with them where Lantal came from and where they wanted to go. The fact that Lantal was consistently able to deliver high quality products also partly resulted from its qualified and experienced employees. Lantal had a very low fluctuation rate and there were families who worked in the third generation in the company. ${ }^{16}$

The culture at FISBA was described as diverse, inclusive and collaborative. CEO Markus Hersche observed that the senior management team functioned well at FISBA and that employees consistently exhibited high levels of engagement and worked well together. Due to this culture, FISBA could develop efficient organizational routines with very little "idle power," according to its CEO. The employees were running a corporate bowling and football club. They often organized get togethers, outings and barbecues. Former CEO Werner Krüsi highlighted the open communication at FISBA and its positive influence on the motivation of employees as one of the success factors of the company. ${ }^{17}$

The importance of preserving this special SME-type management style was also deemed crucial to the company's success when it reached a larger size and the close bond between employees and management was at risk. The experience of Burckhardt Compression, with more than 2000 employees worldwide, was highly relevant in this context.

Valentin Vogt, Chairman and CEO of Burckhardt Compression, was a strong believer in smaller, manageable units. When he took over management of Sulzer-Burckhardt he recalled that, ... there were about 400 people working at the Oberwinterthur location and I knew everyone by name. When organizational units pass 1500 staff, they become slow and lazy, and one starts to hire people who keep others from being productive (Vogt, Chairman and CEO).

Vogt became intrigued by an independent church in the Winterthur area where church leadership kept the congregations at about 1000 and when they grew beyond that, simply created another congregation to start all over again. With more than 1000 church members things became too anonymous. Applying the "Beehive Principle" the church moved to another location in the region creating a new congregation.

\footnotetext{
${ }^{15}$ Adapted from Sécheron Groupe company profile.

${ }^{16}$ Adapted from Lantal company profile.

${ }^{17}$ Adapted from FISBA company profile.
} 
With Burckhardt surpassing 2000 headcount, Vogt was eager to create his own "beehive" experience. The company divided its operations into two distinct parts, one for new machine systems and one for service business, both operated under different key success factors. Vogt likened this organizational move to operating two frigates instead of a single aircraft carrier. Each unit had its own management team, was endowed with autonomy and led by a small holding group on top with only 11 executives and staff. Synergies rarely exist, and they are consistently overvalued by managers (Vogt). ${ }^{18}$

If there was a Swiss style of management for medium-sized firms, it was described as down-to-earth, approachable, informal and with a familiar type of communication across multiple levels, while at the same time being guided by a vision of where the respective industry sector was headed. Some interview partners maintained that there was a clear difference from the Anglo-Saxon style of management.

This everyone-talks-to-everyone style of management appears to be a key ingredient to the success of the firms researched. While size plays a role, it also requires a style of personal interaction and trust that makes this possible. Mutual respect is crucial to this dialog. A management that respects the skills of its employees, and self-confident employees who are aware of the value of their capabilities, are both important ingredients in this exchange.

This difference and uniqueness of the Swiss SME-type management style was most sharply articulated by company leaders who had joined their SME from the outside, usually having worked at a larger company. This suggested to the authors that those CEOs were more acutely aware of the differences in management style between the typical corporate industry environments in comparison to what they experienced when joining an SME. By contrast, leaders who had always been part of the SME environment probably considered this style too obvious and commonplace to comment upon.

Open Access This chapter is licensed under the terms of the Creative Commons Attribution 4.0 International License (http://creativecommons.org/licenses/by/4.0/), which permits use, sharing, adaptation, distribution and reproduction in any medium or format, as long as you give appropriate credit to the original author(s) and the source, provide a link to the Creative Commons license and indicate if changes were made.

The images or other third party material in this chapter are included in the chapter's Creative Commons license, unless indicated otherwise in a credit line to the material. If material is not included in the chapter's Creative Commons license and your intended use is not permitted by statutory regulation or exceeds the permitted use, you will need to obtain permission directly from the copyright holder.

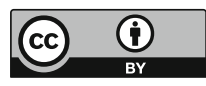

${ }^{18}$ Adapted from Burckhardt Compression company profile. 